\title{
Bilateral trochlear nerve palsy due to cerebral vasculitis related to COVID-19 infection
}

\section{Paralisia bilateral do nervo troclear por vasculite cerebral relacionada à infecção por COVID-19}

Roberto de Magalhães Carneiro de OLIVEIRA', Diogo Haddad SANTOS',

Bruno Casola OLIVETTI², Jorge Tomio TAKAHASHI ${ }^{2}$

A 69-year-old Caucasian man presented fever $\left(38^{\circ} \mathrm{C}\right)$ with abdominal pain, left posterior chest pain without cough or dyspnea, and mild occipital headache that persisted in the next few days. Eleven days later, he woke up with binocular diplopia and severe stabbing occipital headache. There were no peripheral signs of systemic vasculitis. The neurological evaluation identified bilateral paresis of the fourth cranial nerve. He had well-controlled arterial hypertension and denied trauma or use of other medications. COVID-19 infection was confirmed by the reverse transcription technique followed by polymerase chain reaction (RT-PCR) in a nasopharyngeal swab. A brain magnetic resonance imaging (MRI) with MRI angiography and vessel wall imaging showed signs of vasculitis of the vertebrobasilar system ${ }^{1}$, as well as inflammatory radiologic signs in the periaqueductal region, along the topography of the trochlear nuclei (Figure 1). Chest computed tomography (CT) showed peripheral parenchymal ground-glass opacities, suggesting viral pneumonia. Cerebrospinal fluid (CSF) revealed 2 cells $/ \mathrm{mm}^{3}$ (69\% lymphocytes, $29 \%$ monocytes, $2 \%$ macrophages) and proteins slightly increased to $46 \mathrm{mg} / \mathrm{dL}$ (with $17.01 \%$ gamma globulin). CSF antibody testing was negative for syphilis and other viruses. Rheumatological causes, hypovitaminosis, and thyroid dysfunction were ruled out. Erythrocyte sedimentation rate (ESR) was $33 \mathrm{~mm} / \mathrm{h}$. He received IV methylprednisolone for five days with complete improvement of pain and diplopia.

This is the first case report of cerebral vasculitis related to COVID-19 infection in an adult patient. We emphasize that headache ${ }^{2}$ could be a warning sign of cerebral vasculitis in these individuals.
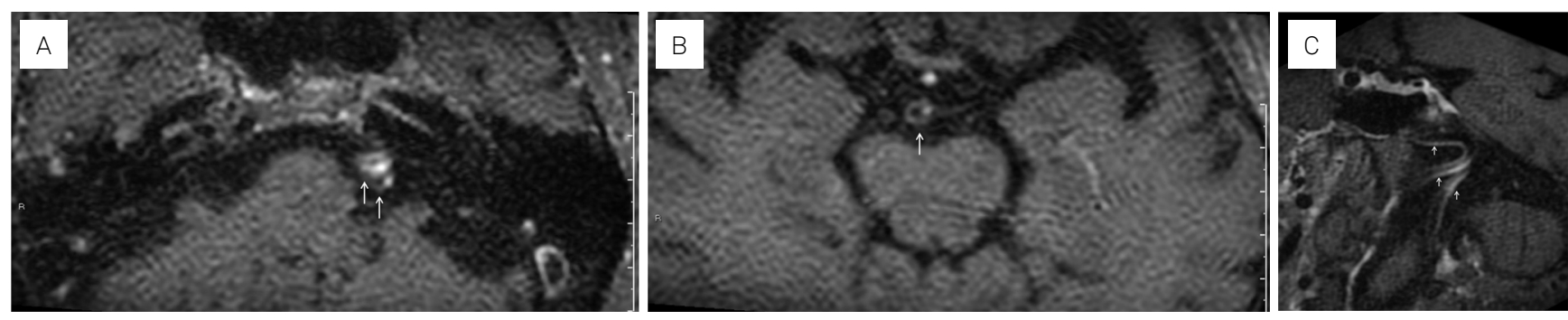

Figure 1. (A and B) axial MRI 3D-T1 FATSAT post-contrast vessel wall imaging at the level of the vertebral arteries (A) and basilar artery (B) shows mild abnormal concentric enhancement of the basilar artery wall (arrow) and intense abnormal concentric enhancement of the vertebral artery wall, which are tortuous and lateralized to the left (arrow). (C) Reformatted Coronal Oblique 3D-T1 FATSAT postcontrast vessel wall imaging shows abnormal concentric enhancement of the basilar and vertebral artery walls (arrows).

\footnotetext{
${ }^{1}$ Hospital Alemão Oswaldo Cruz, Departamento de Neurologia, São Paulo SP, Brazil.

${ }^{2}$ Hospital Alemão Oswaldo Cruz, Departamento de Neurorradiologia, São Paulo SP, Brazil.

Correspondence: Diogo Haddad Santos; Email: dhaddadsantos@gmail.com

Conflict of interest: There is no conflict of interest to declare.

Received on April 29, 2020; Received in its final form on May 06, 2020; Accepted on May 11, 2020.
}

Roberto de Magalhães Carneiro de OLIVEIRA (D) https://orcid.org/0000-0003-4297-8392; Diogo Haddad SANTOS (D) https://orcid.org/0000-0003-1474-1849; Bruno Casola OLIVETTI (D) https://orcid.org/0000-0002-6326-368X; Jorge Tomio TAKAHASHI (D) https://orcid.org/0000-0002-1181-788X 


\section{References}

1. Mandell DM, Mossa-Basha M, Qiao Y, Hess CP, Hui F, Matouk C, et al. Intracranial vessel wall MRI: principles and expert consensus recommendations of the American Society of Neuroradiology. AJNR Am J Neuroradiol. 2017 Feb;38(2):218-29. https://doi.org/10.3174/ajnr.A4893

2. Mao L, Jon H, Wang M, Hu Y, Chen S, He Q, et al. Neurologic manifestations of hospitalized patients with Coronavirus disease 2019 in Wuhan, China. JAMA Neurol. 2020 Apr. [Epub ahead of print]. https://doi.org/10.1001/jamaneurol.2020.1127 